Revista Brasileira de Farmacognosia Brazilian Journal of Pharmacognosy 21(2): 202-208, Mar./Apr. 2011

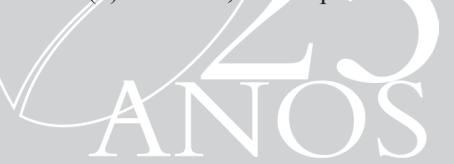

Article

Received 21 Dec 2010

Accepted 2 Feb 2011

Available online 1 Apr 2011

Keywords:

mycosporine-like amino acids

(MAAs)

photoprotective compounds

macroalgae

Gracilaria

HPLC

tandem mass spectrometry

ISSN 0102-695X

doi: 10.1590/S0102-695X2011005000047

\section{Analyses of photoprotective compounds in red algae from the Brazilian coast}

\author{
Karina H. M. Cardozo,, 1 Luiza G. Marques, ${ }^{2}$ Valdemir M. \\ Carvalho, ${ }^{1}$ Mario O. Carignan, ${ }^{3}$ Ernani Pinto, ${ }^{4}$ Eliane \\ Marinho-Soriano, ${ }^{5}$ Pio Colepicolo ${ }^{2}$
}

\author{
${ }^{1}$ Fleury Group, Brazil, \\ ${ }^{2}$ Departamento de Bioquímica, Instituto de Química, Universidade de São Paulo, \\ Brazil, \\ ${ }^{3}$ Instituto Nacional de Investigación y Desarrollo Pesquero, Argentina, \\ ${ }^{4}$ Departamento de Análises Clínicas e Toxicológicas, Faculdade de Ciências \\ Farmacêuticas, Universidade de São Paulo, Brazil, \\ ${ }^{5}$ Departamento de Oceanografia e Limnologia, Universidade Federal do Rio Grande \\ do Norte, Brazil.
}

\begin{abstract}
Qualitative and quantitative studies of mycosporine-like amino acids (MAAs) in three species of the genus Gracilaria Greville ( $G$. birdiae, G. domingensis and G. tenuistipitata) were performed. A simple and efficient extraction procedure based on ethanol was described. HPLC, UV and mass spectrometry experiments revealed different profiles between extracts obtained from one species cultivated in the laboratory ( $G$. tenuistipitata) and two species collected in their natural environment ( $G$. birdiae and $G$. domingensis). The levels detected in the latter two species were approximately 150 times higher than in the species cultivated in vitro. This study revealed that G. birdiae and G. domingensis present a potential source for economical exploration of MAAs.
\end{abstract}

\section{Introduction}

Solar ultraviolet radiation (UVR) exerts deleterious effects on aquatic and terrestrial ecosystems (Häder et al., 1998; Häder \& Sinha, 2005). Since many organisms are light-dependent, they cannot avoid UVR exposure. In order to attenuate the toxic UVR effects, photosynthetic organisms have developed several defense mechanisms. Vertical movement within the water column (Smith et al., 1992), DNA repair by photoreactivation and excision (Britt, 1995) and accumulation of antioxidant compounds (Dunlap \& Yamamoto, 1995; Ehling-Schulz et al., 1997) are some examples of these methods. Another important defense mechanism, developed by cyanobacteria and algae, is the synthesis and accumulation of mycosporine-like amino acids (MAAs), which strongly absorb in the UVR range (Shick \& Dunlap, 2002).

The MAAs are water-soluble compounds present intracellularly in many marine and freshwater organisms (Dunlap \& Shick, 1998; Gröniger et al., 2000, Sinha et al., 2007). They are characterized by a cyclohexenone or cyclohexenimine chromophore conjugated with a nitrogen substituent of an amino acid, amino alcohol or amino group, having absorption maxima ranging from 310 to $360 \mathrm{~nm}$ (Nakamura \& Kobayashi, 1982). Over 25 mycosporines and MAAs have been characterized in fungi and aquatic organisms and this number is increasing with the application of more sensitive methodologies such as mass spectrometry (Volkmann et al., 2006; Carignan et al., 2009).

The biosynthesis of MAA has been reported to occur in bacteria, cyanobacteria and algae. Other aquatic organisms acquire them through diet transfer and also by symbiotic or bacterial association (Shick et al., 1992; Stochaj et al., 1994; Carroll \& Shick, 1996). Biosynthesis of MAAs is not yet fully understood. It was hypothesized that MAA synthesis derives from a branch of the shikimate pathway, which is responsible for the synthesis of the aromatic amino acids phenylalanine, tyrosine and tryptophan. This hypothesis was tested with the use of radioactive labeling of shikimic acid intermediates in fungus (Favre-Bonvin et al., 1987) and inhibition of the pathway with glyphosate in coral (Shick et al., 1999). However, a recent study contradicted this theory by showing that an enzyme 
<smiles>COC1=C(NCC(=O)O)CC(O)(CO)CC1=NC(CO)C(=O)O</smiles>
shinorine (1)<smiles>COC1=C(NCC(=O)O)CC(O)(CO)CC1=N</smiles>

palythine (2)<smiles>COC1=C(NCC(=O)O)CC(O)(CO)CC1=NCCO</smiles>

asterina-330 (3)<smiles>COC1=C(NCC(=O)O)CC(O)(CO)C/C1=N\C(C(=O)O)C(C)O</smiles>

porphyra-334 (4)<smiles>COC1=C(NCC(=O)O)CC(O)(CO)C/C1=N/C(C)CO</smiles>

palythinol (5) involved in the synthesis of the MAA shinorine (1) utilizes a pentose phosphate pathway intermediate instead of the shikimate pathway intermediate (Balksus \& Walsh, 2010).

The photoprotective function of MAAs in marine organisms can be inferred from their efficiency of absorbing ultraviolet A (320-400 nm) and ultraviolet B (280-320 $\mathrm{nm})$ radiation due to their high molar absorption coefficients and frequent observations correlating higher MAAs concentrations with higher levels of UVR (Klisch \& Häder, 2000; Sinha et al., 2000; Arróniz-Crespo et al., 2005). Besides their function as photoprotective compounds, it has been suggested that MAAs also have antioxidant activity (Dunlap \& Yamamoto, 1995), osmotic functions (Oren, 1997) and a regulatory role in reproduction (Bandaranayake \& Des Rocher, 1999).

Their photoprotective properties have been already explored in commercial formulations. For instance, Helioguard $365^{\circledR}$ is a mixture of MAAs used in skin care products. They also have been considered as photostabilizers for plastics and dyes and are the subject of several patents because of their commercial relevance (Miyamoto et al., 2009; Aguilera et al., 2009; Schmid et al., 2004). Despite their economical importance, no synthetic routes to prepare MAAs are available; therefore, they are obtained exclusively from natural sources.

Given their expressive economic exploration, the Rhodophyta (red algae) are promising sources of secondary metabolites, including MAAs (Takamatsu et al., 2003; Cardozo et al., 2007; Blunt et al., 2010;
Machado et al., 2010; Lhullier et al., 2010). In fact, some reports describe that MAAs are found in the Rhodophyta in higher concentrations and greater diversity when compared with Phaeophyta and Chlorophyta (Karsten et al., 1998a,b). Moreover, the amount of MAAs in the tropical Rhodophyta seems to be higher than in temperate organisms, possibly reflecting acclimatization to the stronger solar radiation typical of lower latitudes (Karsten et al., 1998a). Among the red algae, a genus of great economical interest is Gracilaria Greville, known for producing high-quality agar. The widespread use of agar in the food, pharmaceutical and cosmetic industries promotes their worldwide cultivation, including in Asia, Southern Africa and South America. These cultivations are also being made in association with animal aquacultures (Marinho-Soriano et al., 2009; Salles et al., 2010) in order to attenuate the culture's impact on coastal waters, since the release of large amounts of nutrients into aquatic ecosystems can lead to eutrophication. The production of a secondary crop (algae) in an integrated cultivation system could improve water quality and provide extra income through exploration of agar and MAAs.

The present work reports the characterization and MAAs composition of two economically important macroalgae of the genus Gracilaria cultivated in the northeast of Brazil. The MAAs profile is compared with $G$. tenuistipitata, a model red macroalgae routinely cultivated since 1993 in the laboratory. To our knowledge, this is the first report of the detection of MAAs in Gracilaria species grown on the Brazilian coast. 


\section{Materials and Methods}

\section{Chemicals}

All solvents used were HPLC grade (Tedia, São Paulo, Brazil and J. T. Baker, Phillipsburg, USA). The remaining chemicals were from Sigma-Aldrich (St. Louis, USA). Ultrapure water was obtained from a Milli-Q system (Millipore, Bedford, USA).

\section{Organisms}

Gracilaria birdiae Plastino et Oliveira and Gracilaria domingensis (Kützing) Sonder ex Dickie were collected from Praia do Cotovelo (05 $56^{\prime} \mathrm{S}$ $\left.035^{\circ} 09^{\prime} \mathrm{W}\right)$, located on the south coast of Rio Grande do Norte State, Brazil. The samples were kept at $-80^{\circ} \mathrm{C}$ until MAAs extraction.

Gracilaria tenuistipitata var. liui Zhang et Xia (strain 63) from Haikou, China, was collected and decontaminated by E. C. Oliveira in 1993 and deposited in the germoplasm bank at the Institute of Biosciences of the University of São Paulo (Lourenço $\&$ Vieira, 2004). The cultures were maintained at 20 ${ }^{\circ} \mathrm{C}$ under constant air bubbling in 2 L-flasks containing von Stosch medium (Edwards, 1970) under a $12 \mathrm{~h}$ photoperiod (cool white fluorescent lights; $90 \mu \mathrm{mol}$ photons $\left.\mathrm{m}^{-2} \mathrm{~s}^{-1}\right)$. Samples were frozen in liquid nitrogen and kept at $-80{ }^{\circ} \mathrm{C}$ until MAAs extraction.

\section{Sample preparation}

Frozen algal samples were homogenized in a blender with liquid nitrogen and extracted at $4{ }^{\circ} \mathrm{C}$ for $24 \mathrm{~h}$ with organic solvent and water. Different extraction solvent compositions were evaluated: $20 \%$ methanol, 50\% methanol, 20\% ethanol and 50\% ethanol ( $\mathrm{v} / \mathrm{v}$ in water). The extracts were then filtered and the algal debris reextracted as described previously. This procedure was repeated until spectrophotometric analysis (scan range 250-400 $\mathrm{nm}$ ) revealed the absence of MAAs in the extracts. The combined extracts were centrifuged (10000 $\mathrm{rpm} / 10 \mathrm{~min})$ and evaporated in a speed-vacuum (SpeedVac, Savant, Farmingdale, USA). Dried extracts were solubilized in $0.1 \%$ formic acid and analyzed by HPLC with photodiode array (DAD) and mass spectrometry detection.

\section{Chromatographic and mass spectrometric conditions}

Qualitative analyses of MAAs were performed using a Shimadzu Prominence liquid chromatographer with photodiode array (Shimadzu Co., Kyoto, Japan) and ion trap mass spectrometer detectors (Esquire HCT, Bruker Daltonics, Billerica, USA) equipped with an electrospray source. Separation was performed using two columns in tandem: Synergi Polar-RP (Phenomenex, $250 \times 4.6 \mathrm{~mm}, 4 \mu \mathrm{m}$ ) and Synergi Fusion RP (Phenomenex, $250 \times 4.6 \mathrm{~mm}, 4 \mu \mathrm{m}$ ) at $30{ }^{\circ} \mathrm{C}$. The solvent system was an aqueous solution of $0.1 \% \mathrm{pH} 3.14$ ammonium formate in pump A and methanol in pump B. The selected conditions started with $0 \%$ of solvent $\mathrm{B}$ during the first $10 \mathrm{~min}$; then a linear increase from 0 to $50 \%$ of B between 10 and $20 \mathrm{~min}$; maintaining $50 \%$ of $\mathrm{B}$ for $10 \mathrm{~min}$, with a total run of $40 \mathrm{~min}$. The flow

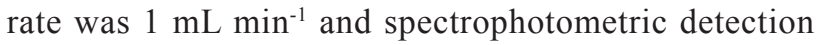
was performed at $330 \mathrm{~nm}$. Multi-stage mass analyses on the ion trap instrument were achieved in the positive ion mode using nitrogen as the nebulising (10 psi) and drying $\left(4 \mathrm{~L} \mathrm{~min}^{-1}, 300{ }^{\circ} \mathrm{C}\right)$ gas and helium as the buffer gas $\left(4 \times 10^{-6} \mathrm{mbar}\right)$. Capillary high voltage was set to $3500 \mathrm{~V}$. To avoid space-charge effects, the smart ion charge control (ICC) was set to the arbitrary value of 100,000 with a maximum accumulation time of 100 $\mathrm{ms}$. Isolation width was $2.0 \mathrm{Da}$ and a collision energy of $30 \%$ was used for tandem mass spectrometry $\left(\mathrm{MS}^{2}\right.$ and $\mathrm{MS}^{3}$ ) experiments. Five spectra were averaged for each data point. High-resolution mass analyses of the extracts were obtained using a quadrupole orthogonal time-of-flight mass spectrometer (Q-TOF, Micromass/ Waters, Manchester, UK). The needle voltage was set at $3.3 \mathrm{kV}$ and the cone voltage at $35 \mathrm{~V}$. Nitrogen was used as nebulising gas. Argon was used as the collision gas with the collision energy set at $4 \mathrm{eV}$.

Quantitative analyses of the extracts were performed according to the previously published HPLC method (Carreto et. al., 2005).

\section{Results and Discussion}

In this study, the effect of different organic solvents was evaluated to achieve the most efficient extraction of MAAs from three species of the genus Gracilaria Greville (G. birdiae, G. domingensis and $G$. tenuistipitata). Analysis by HPLC with DAD detection revealed that the extraction with $20 \%$ methanol was the most efficient and with $50 \%$ ethanol was the least efficient among the tested combinations (data not shown). These findings are in agreement with a previous report describing higher yields of MAAs when 25\% methanol was used instead of $100 \%$ methanol (Tartarotti \& Sommaruga, 2002). Although, higher yields can be obtained with $20 \%$ methanol, we found that $20 \%$ ethanol is an effective alternative. Since ethanol is less expensive and less toxic than methanol, it could make extraction on large scale more feasible.

The HPLC-DAD chromatograms of the ethanolic extracts from the three species of red macroalgae are shown in Figure 1. The identity of each peak was inferred from UV spectra and from ESI-MS ${ }^{\mathrm{n}}$ 
analysis by comparison with the fragmentation patterns previously described (Cardozo et al., 2006; Cardozo et al., 2008) (Table 1). In addition, the identity of each MAA was confirmed by accurate-mass measurement after isolation of the peaks (Table 2). Five MAAs were identified in the three macroalgae tested: shinorine (1), palythine (2), asterina-330 (3), porphyra-334 (4) and palythinol (5).
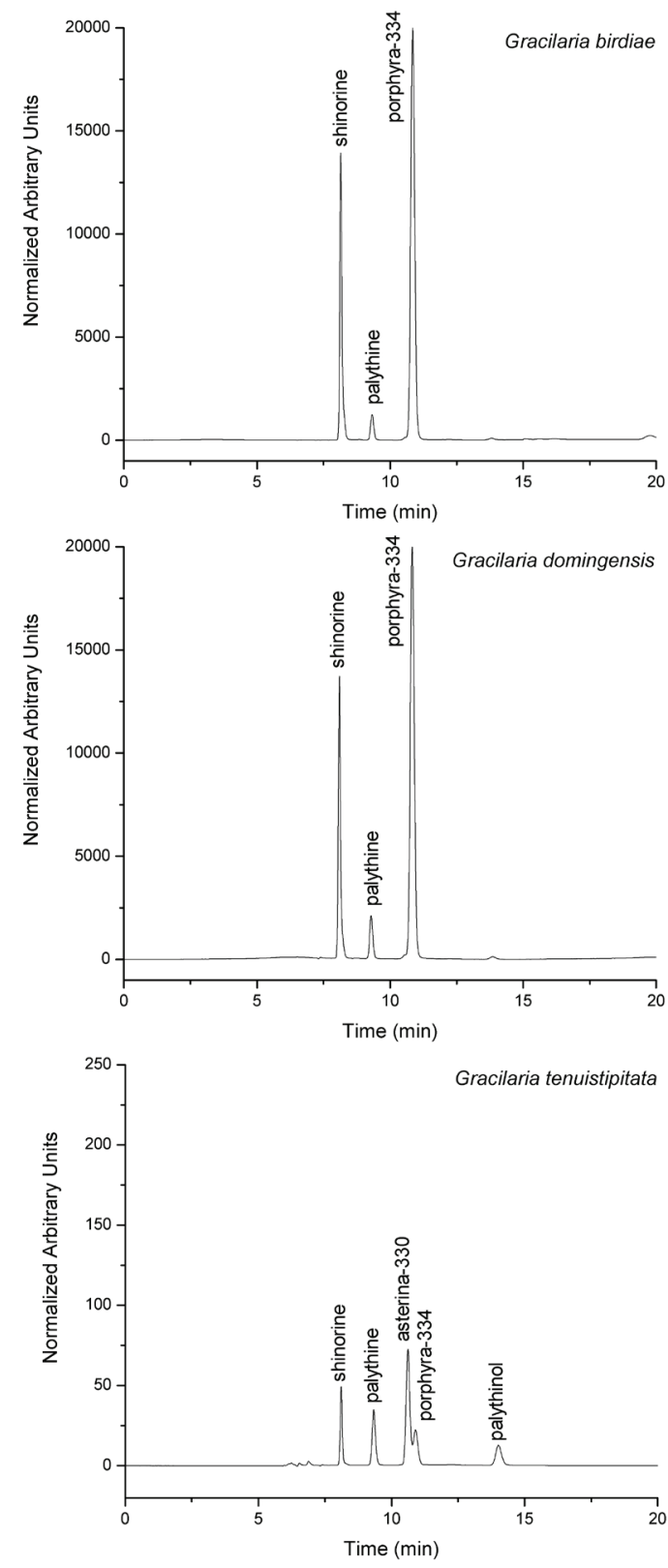

Figure 1. HPLC-DAD $(330 \mathrm{~nm})$ chromatograms of mycosporine-like amino acids detected in three species of Gracilaria Greville. G. birdiae and G. domingensis were collected from the sea and $G$. tenuistipitata was cultivated in the laboratory.
Quantitative analyses of MAAs were performed on the ethanolic extracts as previously described (Carreto et al., 2005). Identification of MAAs was inferred by their absorption maxima, retention time and by co-chromatography with authentic standards. Two distinct patterns of MAAs distribution were observed in three Gracilaria species (Table 3 ). The species cultivated in vitro ( $G$. tenuistipitata) presented similar levels of shinorine (1), palythine (2), asterina-330 (3), porphyra-334 (4) and palythinol (5). Asterina-330 was the most abundant MAA, corresponding to $40 \%$ of the total MAAs identified. In the species collected from the natural environment ( $G$. birdiae and $G$. domingensis) only shinorine (1), palythine (2) and porphyra-334 (4) were detected at levels above the lower limit of quantitation. Porphyra-334 (4) was the most abundant MAA in $G$. birdiae and G. domingensis, corresponding to approximately $70 \%$ of the total MAAs. Interestingly, not only the MAAs composition, but also the concentration differ substantially (Table 3). The concentration of MAAs was 40 to 700 times higher in G. birdiae and $G$. domingensis than in $G$. tenuistipitata. This expressive difference should be studied further, but it is possibly related to the higher exposure to solar UVR in the species collected from the sea compared to that cultivated in vitro. In fact, the amount of MAAs is higher in the tropical Rhodophyta than in those from temperate regions, which might be explained by the acclimatization to the more intense solar radiation typical of lower latitudes (Karsten et al., 1998a).

The ethanolic extract of $G$. birdiae and $G$. domingensis resulted in a yield of $1.5 \%$, of which $2.7 \%$ (G. birdiae) and 2.9\% (G. domingensis) corresponded to MAAs content. This good yield reflects the high amounts of these compounds found in these species cultivated at latitudes with high incidence of UVR. Therefore, G. birdiae and G. domingensis are potential sources of MAAs for economical exploration.

\section{Conclusion}

MAAs are important photoprotective compounds that can be obtained from two species of Gracilaria cultivated in northeastern coast of Brazil in good yields via simple extraction procedure. The association of algae cultivation with animal aquacultures has already been implemented and has positive effects on the protection from eutrophication phenomena. The presence of high levels of MAAs in algae, as described in this study, offers a new source of income for communities that depend on aquaculture for their subsistence. 
Table 1. Identification of mycosporine-like amino acids by chromatography, spectrophotometry and mass spectrometry.

\begin{tabular}{lcccc}
\hline Compound & TR $(\min )$ & $\lambda_{\max }(\mathrm{nm})$ & {$[\mathrm{M}+\mathrm{H}]^{+}$} & Fragments \\
\hline Shinorine (1) & 8.1 & 332 & 333 & $186,230,274,303318$ \\
Palythine (2) & 9.3 & 319 & 245 & $186,197,209,230$ \\
Asterina-330 & 10.6 & 333 & 289 & $186,209,230,274$ \\
Porphyra-334 (4) & 10.9 & 333 & 347 & $186,227,288,303,332$ \\
Palythinol (5) & 14.1 & 331 & 303 & $186,230,244,288$ \\
\hline
\end{tabular}

Table 2. Accurate-mass measurements of isolated mycosporine-like amino acids.

\begin{tabular}{lcccc}
\hline Protonated molecule $[\mathrm{M}+\mathrm{H}]^{+}$ & Observed $m / z$ value & Calculated $m / z$ value & Error $(\mathrm{ppm})$ & Formula \\
\hline Shinorine (1) & 333.1304 & 333.1298 & 1.8 & $\mathrm{C}_{13} \mathrm{H}_{21} \mathrm{~N}_{2} \mathrm{O}_{8}$ \\
Palythine (2) & 245.1146 & 245.1138 & 3.2 & $\mathrm{C}_{10} \mathrm{H}_{17} \mathrm{~N}_{2} \mathrm{O}_{5}$ \\
Asterina-330 (3) & 289.1395 & 289.1400 & -1.0 & $\mathrm{C}_{12} \mathrm{H}_{21} \mathrm{~N}_{2} \mathrm{O}_{6}$ \\
Porphyra-334 (4) & 347.1433 & 347.1449 & -4.0 & $\mathrm{C}_{14} \mathrm{H}_{23} \mathrm{~N}_{2} \mathrm{O}_{8}$ \\
Palythinol (5) & 303.1559 & 303.1556 & 1.0 & $\mathrm{C}_{13} \mathrm{H}_{23} \mathrm{~N}_{2} \mathrm{O}_{6}$ \\
\hline
\end{tabular}

Table 3. Distribution and content of mycosporine-like amino acids in three species of Gracilaria Greville.

\begin{tabular}{lccc}
\hline & \multicolumn{3}{c}{ Content of MAA $\left(\mathrm{mg} \mathrm{g}\right.$ extract $\left.{ }^{-1}\right)$} \\
\cline { 2 - 4 } Compound & G. birdiae & G. domingensis & G. tenuistipitata \\
\hline Shinorine (1) & 6.5 & 7.2 & 0.0264 \\
Palythine (2) & 2.4 & 1.9 & 0.0454 \\
Asterina-330 (3) & nd & nd & 0.0728 \\
Porphyra-334 (4) & 18.3 & 20.0 & 0.0278 \\
Palythinol (5) & nd & nd & 0.0197 \\
Total & 27.2 & 29.1 & 0.1921 \\
\hline
\end{tabular}

MAA: Mycosporine-like amino acids. The absence of a MAA is indicated as not detected (nd).

\section{Acknowledgements}

This work was supported by Fundação de Amparo à Pesquisa do Estado de São Paulo, Coordenação de Aperfeiçoamento de Pessoal de Nível Superior, Conselho Nacional de Desenvolvimento Científico e Tecnológico, Ministério da Saúde, Ministério de Ciência e Tecnologia and CNPqINCT-Redoxoma.

\section{References}

Aguilera AJ, De La Coba LF, Korbee PN, Lopez FF 2009. Composition for preparing sunscreen, comprises antioxidants such as mycosporine-like amino acids, porphyra isolated from red algae and mycosporineglycine isolated from marine lichen. ES2317741-A1; ES2317741-B1

Arróniz-Crespo M, Sinha RP, Martinez-Abaigar J, Nunez-Olivera E, Häder DP 2005. Ultraviolet radiation-induced changes in mycosporine-like amino acids and physiological variables in the red alga Lemanea fluviatilis. J Freshw Ecol 20: 677-687.

Balksus EP, Walsh CT 2010. The genetic and molecular basis for sunscreen biosynthesis in cyanobacteria. Science 329: 1653-1656.
Bandaranayake WM, Des Rocher A 1999. Role of secondary metabolites and pigments in the epidermal tissues, ripe ovaries, viscera, gut contents and diet of the sea cucumber Holothuria atra. Mar Biol 133: 163169.

Blunt JW, Copp BR, Munro MHG, Northcote PT, Prinsep MR 2010. Marine natural products. Nat Prod Rep 27: 165-237.

Britt AB 1995. Repair of DNA damage induced by ultraviolet radiation. Plant Physiol 108: 891-896.

Cardozo KHM, Carvalho VM, Pinto E, Colepicolo P 2006. Fragmentation of mycosporine-like amino acids by hydrogen/deuterium exchange and electrospray ionisation tandem mass spectrometry. Rapid Commun Mass Spectrom 20: 253-258.

Cardozo KHM, Vessecchi R, Carvalho VM, Pinto E, Gates PJ, Colepicolo P, Galembeck SE, Lopes NP 2008. A theoretical and mass spectrometry study of the fragmentation of mycosporine-like amino acids. Int J Mass Spectrom 273: 11-19.

Cardozo KHM, Guaratini T, Barros MP, Falcão VR, Tonon AP, Lopes NP, Campos S, Torres MA, Souza AO, Colepicolo P, Pinto E 2007. Metabolites from algae with economical impact. Comp Biochem Physiol C- Toxicol Pharmacol 146: 60-78.

Carignan MO, Cardozo KHM, Oliveira-Silva D, Colepicolo P, Carreto JI 2009. Palythine-threonine, a major 
novel mycosporine-like amino acid (MAA) isolated from the hermatypic coral Pocillopora capitata. $J$ Photochem Photobiol B-Biol 94: 191-200.

Carroll AK, Shick JM 1996. Dietary accumulation of UVabsorbing mycosporine-like amino acids (MAAs) by the green sea urchin (Strongylocentrotus droebachiensis). Mar Biol 124: 561-569.

Carreto JI, Carignan MO, Montoya NG 2005. A highresolution reverse-phase liquid chromatography method for the analysis of mycosporine-like amino acids (MAAs) in marine organisms. Mar Biol 146: 237-252.

Dunlap WC, Shick JM 1998. Ultraviolet radiationabsorbing mycosporine-like amino acids in coral reef organisms: a biochemical and environmental perspective. J Phycol 34: 418-430.

Dunlap WC, Yamamoto Y 1995. Small-molecule antioxidants in marine organisms: antioxidant activity of mycosporine-glycine. Comp Biochem Physiol 112B: 105-114.

Edwards P 1970. Illustrated guide to sea weeds and sea grasses, in the vicinity of Porto Aransas. Texas Contr Mar Sc 15: 1-228.

Ehling-Schulz M, Bilger W, Scherer S 1997. UV-Binduced synthesis of photoprotective pigments and extracellular polysaccharides in the terrestrial cyanobacterium Nostoc commune. J Bacteriol 179: 1940-1945.

Favre-Bonvin J, Bernillon J, Salin N, Arpin N 1987. Biosynthesis of mycosporines: mycosporine glutaminol in Trichothecium roseum. Phytochemistry 29: 2509-2514.

Gröniger A, Sinha RP, Klisch M, Häder DP 2000. Photoprotective compounds in cyanobacteria, phytoplankton and macroalgae - a database. $J$ Photochem Photobiol B, Biol 58: 115-122.

Häder DP, Kumar HD, Smith RC, Worrest RC 1998. Effects on aquatic ecosystems. $J$ Photochem Photobiol B, Biol 46: 53-68.

Häder DP, Sinha RP 2005. Solar ultraviolet radiationinduced DNA damage in aquatic organisms: potential environmental impact. Mutat Res, Fundam Mol Mech Mutagen 571: 221-233.

Karsten U, Sawall T, Wiencke C 1998a. A survey on the distribution of UV-absorbing substances in tropical macroalgae. Phycological Res 46: 271-279.

Karsten U, Sawall T, Hanelt D, Bischof K, Figueroa FL, Flores-Moya A, Wiencke C 1998b. An inventory of UV-absorbing mycosporine-like amino acids in macroalgae from polar to warm-temperate regions. Bot Marina 41: 443-453.

Klisch M, Häder DP 2000. Mycosporine-like amino acids in the marine dinoflagellate Gyrodinium dorsum: induction by ultraviolet irradiation. $J$ Photochem Photobiol B, Biol 55: 178-182.

Lourenço SO, Vieira AAH 2004. Culture collections of microalgae in Brazil: progress and constraints. Nova Hedwigia 79: 149-173.

Lhullier C, Falkenberg M, Ioannou E, Quesada A, Papazafiri P, Horta PA, Schenkel EP, Vagias C, Roussis V 2010. Cytotoxic halogenated metabolites from the Brazilian red alga Laurencia catarinensis. J Nat Prod 73: 27-32.

Marinho-Soriano E, Nunes SO, Carneiro MAA, Pereira DC 2009. Nutrients' removal from aquaculture wastewater using the macroalgae Gracilaria birdiae. Biomass Bioenerg 33: 327-331.

Machado FLD, Kaiser CR, Costa SS, Gestinari LM, Soares AR 2010. Biological activity of the secondary metabolite from marine algae of the genus Laurencia. Rev Bras Farmacogn 20: 441-452.

Miyamoto M, Sakakibara M, Torii M 2009. Novel mycosporine-like amino acid derivative having glycosyl group useful in ultraviolet absorber and ultraviolet-radiation-protection cosmetics for exhibiting UV absorption effect and moisturizing effect. JP2009120562-A

Nakamura H, Kobayashi J 1982. Separation of mycosporine-like amino acids in marine organisms using reversed-phase high-performance liquid chromatography. J Chromatogr 250: 113-118.

Oren A 1997. Mycosporine-like amino acids as osmotic solutes in a community of halophilic cyanobacteria. Geomicrobiol J 14: 231-240.

Salles JP, Scherner F, Yoshimura CY, Fanganiello M, Bouzon ZL, Horta PA 2010. Cultivation of native seaweed Gracilaria domingensis (Rhodophyta) in Southern Brazil. Braz Arch Biol Technol 53: 633640 .

Schmid D, Schuerch C, Zuelli F 2004. Harmless, natural cosmetic skin treatment compositions, for protecting against UV-A induced lipid oxidation and premature aging, containing mycosporine-like amino acids. EP1473028-A1

Shick JM, Dunlap WC 2002. Mycosporine-like amino acids and related gadusols: biosynthesis, accumulation, and UV-protective functions in aquatic organisms. Annu Rev Physiol 64: 223-262.

Shick JM, Romaine-Lioud S, Ferrier-Page's C, Gattuso JP 1999. Ultraviolet-B radiation stimulates shikimate pathway-dependent accumulation of mycosporinelike amino acids in the coral Stylophora pistillata despite decreases in its population of symbiotic dinoflagellates. Limnol Oceanogr 44: 1667-1682.

Shick JM, Dunlap WC, Chalker BE, Banaszak AT, Rosenzweig TK 1992. Survey of ultraviolet radiation-absorbing mycosporine-like amino acids in organs of coral reef holothuroids. Mar Ecol Prog Ser 90: 139-148.

Sinha RP, Klisch M, Gröniger A, Häder DP 2000. Mycosporine-like amino acids in the marine red alga Gracilaria cornea - effects of UV and heat. Environ Exp Bot 43: 33-43.

Sinha RP, Singh SP, Häder DP 2007. Database on mycosporine and mycosporine-like amino acids (MAAs) in fungi, cyanobacteria, macroalgae, phytoplankton and animals. J Photochem Photobiol B, Biol 89: 29-35.

Smith RC, Prezelin BB, Baker KS 1992. Ozone depletion: ultraviolet radiation phytoplankton biology in Antarctic waters. Science 255: 952-959.

Stochaj WR, Dunlap WC, Shick JM 1994. Two new UV- 
absorbing mycosporine-like amino acids from the sea anemone Anthopleura elegantissima and the effects of zooxanthellae and spectral irradiance on chemical composition and content. Mar Biol 118: 149-156.

Takamatsu S, Hodges TW, Rajbhandari I, Gerwick WH, Hamann MT, Nagle DG 2003. Marine natural products as novel antioxidants prototypes. $J$ Nat Prod 66: 605-608.

Tartarotti B, Sommaruga R 2002. The effect of different methanol concentrations and temperatures on the extraction of mycosporine-like amino acids (MAAs) in algae and zooplankton. Archiv für Hydrobiologie 154: 691-703.
Volkmann M, Gorbushina AA, Kedar L, Oren A 2006. Structure of euhalothece-362, a novel red-shifted mycosporine-like amino acid, from a halophilic cyanobacterium (Euhalothece sp.). FEMS Microbiol Lett 258: 50-54.

\section{*Correspondence}

Karina H. M. Cardozo

Fleury Group

Av. Gal. Valdomiro de Lima, 508, 04344-070 São PauloSP, Brazil

karina.cardozo@fl eury.com.br

Tel. +55 1150147570

Fax: +551132872566 